\title{
How Do The EV Project Participants Feel About Charging \\ Their EV Away From Home?
}

\author{
James E. Francfort
}

February 2015

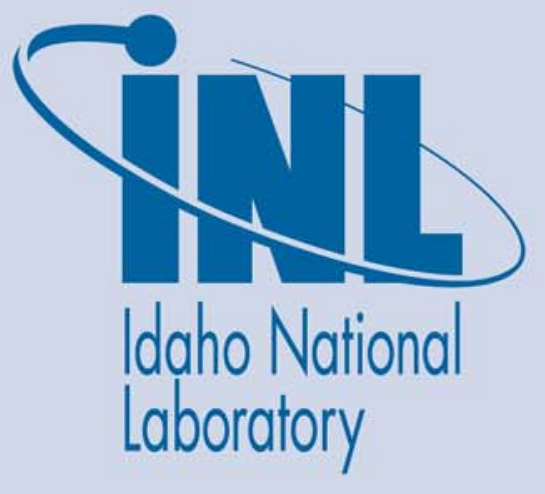

The INL is a U.S. Department of Energy National Laboratory operated by Battelle Energy Alliance 
INL/EXT-15-34559

\title{
How Do The EV Project Participants Feel About Charging Their EV Away From Home?
}

\author{
James E. Francfort
}

February 2015

\author{
Idaho National Laboratory \\ Idaho Falls, Idaho 83415
}

http://www.inl.gov

Prepared for the

U.S. Department of Energy

Office of Energy Efficiency and Renewable Energy

Under DOE Idaho Operations Office

Contract DE-AC07-05ID14517 


\section{EVProject}

\section{How Do The EV Project Participants Feel About Charging Their EV Away From Home?}

February 2015

\section{Key Observations from the Survey of The EV Project Participants}

- In June $2013,41 \%$ of survey respondents who used their plug-in electric vehicle (PEV) for work reported having the availability of charging at their workplace.

- For those who had workplace charging available, nearly twice as many reported alternating current (AC) Level 2 being available as Level 1 .

- $36 \%$ of survey respondents reported that workplace charging was very important or essential to meeting their PEV driving needs.

- $69 \%$ of survey respondents reported they very rarely or never used publicly accessible charging.

- $34 \%$ of survey respondents suggested that expanding the availability of public charging would result in its greater use.

\section{Introduction}

The EV Project is an infrastructure study that enrolled over 8,000 residential participants. These participants purchased or leased a Nissan Leaf battery electric vehicle or Chevrolet Volt extended-range electric vehicle and were among the first to explore this new electric drive technology. Collectively, battery electric vehicles, extended-range electric vehicles, and plug-in hybrid electric vehicles are called PEVs. The EV Project participants were very cooperative and enthusiastic about their participation in the project and very supportive in providing feedback and information. The information and attitudes of these participants concerning their experience with their PEVs were solicited using a survey in June 2013. At that time, some had up to 3 years of experience with their PEVs.

\section{Why Is How the Owner Feels About Away-From-Home Charging Important?}

PEVs require recharging to sustain the battery for electric drive transportation. The owner of the PEV essentially has three choices for charging: home, workplace, or public locations. How the participant felt about home charging was explored in "EV Project Participant and Charging at Home." This current report focuses on their away-fromhome charging experience.

The EV Project participants were the innovators and early adopters of electric drive transportation. Their feedback on how they felt about charging their PEV is of interest because it can shape this new technology for wider adoption.

\section{Participant Information}

Understanding the demographics of The EV Project participant is important in understanding their choices and attitudes toward electric transportation. The age, gender, average household income, and education level were explored in "Who are the Participants in The EV Project?"2

Satisfaction of participants with their PEVs was explored in "How do The EV Project Participants feel about their EVs?"3

The Nissan Leaf sales rollout plan defined the initial five regions of The EV Project, anticipating them to be the location of the innovators and early adopters of PEVs. Later expansion of The EV Project included 16 metropolitan areas in nine states plus the District of Columbia. Within these regions, physical study boundaries were established. The views and attitudes of project participants nationally and regionally are explored in this report.

\section{Which Plug-In Electric Vehicle did they Acquire?}

The EV Project achieved full enrollment of residential participants early in 2013. Final enrollment in each market was ultimately determined by the PEV market conditions, which were driven by local PEV dealer promotions and local government incentives and local demographics. Table 1 identifies the number of participants driving Nissan Leafs and Chevrolet Volts in each region. Because of other U.S. Department of Energy (DOE) projects in the area,

Chevrolet Volt drivers were not included in The EV Project in the San Francisco region.

Table 1. Regional participation in The EV Project.

\begin{tabular}{|l|c|c|}
\cline { 2 - 3 } \multicolumn{1}{c|}{} & Leaf & Volt \\
\hline Arizona & 376 & 156 \\
Los Angeles & 471 & 344 \\
San Diego & 722 & 277 \\
San Francisco & 1,874 & - \\
Oregon & 558 & 136 \\
Washington State & 969 & 177 \\
Tennessee & 942 & 144 \\
Texas & 34 & 288 \\
Washington D.C. & 50 & 291 \\
Atlanta & 176 & 77 \\
Chicago & 34 & 129 \\
Philadelphia & 32 & 54 \\
\hline Overall & 6,238 & 2,073 \\
\hline
\end{tabular}

The original completion date of The EV Project was December 2012. Later expansion of the project also 
extended the completion date to December 2013. Some participants retired from the Project at the end of the original period. In addition, some other participants retired because they sold their vehicles or their vehicles were destroyed in accidents.

\section{Participant Survey}

For participants in The EV Project, residential charging is accomplished through the use of the AC Level 2 EVSE. AC Level 2 uses a 240-volt circuit in the home similar to that used for a clothes dryer or hot water heater. The EV Project participants were provided the Blink AC Level 2 charging station for their residence at no cost, along with a specified credit toward the cost of installation of that station, in exchange for their agreement to allow The EV Project to collect and use their residential and nonresidential charging and vehicle data.

One goal of The EV Project was to gain an understanding of participant experience and attitudes toward their PEV usage. In support of this goal, an online survey sent to 7,730 active EV Project participants. The survey solicited 3,236 responses for a $42 \%$ response rate. Among the topics identified were questions related to charging their PEV battery away from home. Table 2 presents the responses received by region and vehicle type.

Table 2. Survey responses by region.

\begin{tabular}{|l|c|c|c|}
\cline { 2 - 4 } \multicolumn{1}{c|}{} & $\begin{array}{c}\text { Leaf } \\
\text { Responses }\end{array}$ & $\begin{array}{c}\text { Volt } \\
\text { Responses }\end{array}$ & $\begin{array}{c}\text { Leaf and Volt } \\
\text { Responses }\end{array}$ \\
\hline Arizona & 159 & 74 & 1 \\
Los Angeles & 133 & 120 & 7 \\
San Diego & 244 & 109 & 7 \\
San Francisco & 553 & - & 4 \\
Oregon & 211 & 74 & 2 \\
Washington State & 378 & 83 & 3 \\
Tennessee & 345 & 54 & 2 \\
Texas & 11 & 119 & 2 \\
Washington D.C. & 13 & 114 & 2 \\
Atlanta & 74 & 39 & 1 \\
Chicago & 15 & 67 & - \\
Philadelphia & 13 & 26 & 1 \\
Unknown & 159 & 2 & 2 \\
\hline Overall & 2,308 & 881 & 34 \\
\hline
\end{tabular}

Thirty-four of the respondents reported having both a Leaf and a Volt in The EV Project and 13 reported they were no longer participating; 163 responses were provided that identified the type of vehicle but not the region of The EV Project.

\section{Charging Away from Home}

The EV Project's quarterly reports have identified that about $20 \%$ of all charging events for the Leaf and $14 \%$ of all charging events for the Volt occur away from home. ${ }^{4}$
This includes both publicly accessible and workplace charging. The first series of questions deals with workplace charging.

\section{Workplace Charging}

\section{Availability and Use of Workplace Charging}

Participants were asked, "Do you have access to charging at work?" The response choices provided were as follows:

- Yes, I often or sometimes use it.

- Yes, I have access, but I never or rarely use it.

- No, but I would use it if it were available.

- No and I would not use it if it were available.

- I don't know.

- NA, I don't use my EV for work.

In all, 2,961 responses were received. Of those, 382 indicated they did not use their EV for work. The responses from the remaining 2,579 are shown in Figure 1.

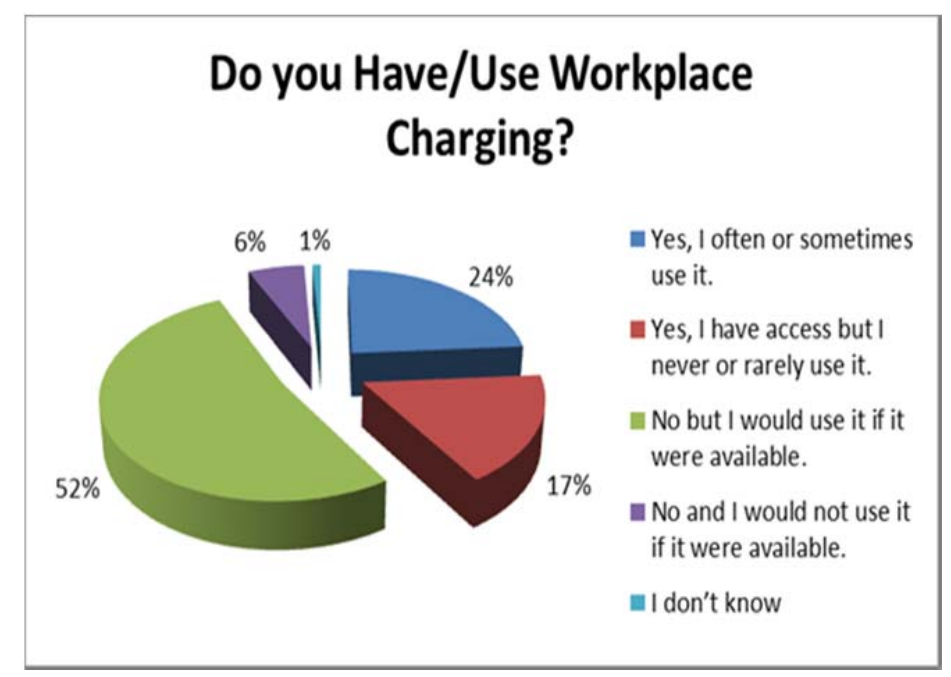

Figure 1. Availability and use of workplace charging.

Workplace charging was available for 1,058 of The EV Project survey respondents. It is significant that this many employers provided this benefit for employees, given the early stage in EV deployment. It is not clear from the survey whether the availability of workplace charging was a factor in the participant's decision to purchase a PEV.

The regional availability of workplace charging for those who used their EV for work is shown in Figure 2.

Overall, $41 \%$ of the respondents who used their PEV for work commuting had access to workplace charging. For those who had availability of workplace charging, proportionally more Volt owners declined to use it. The responses of the Leaf and Volt owners about availability and use are shown in Figure 3. 


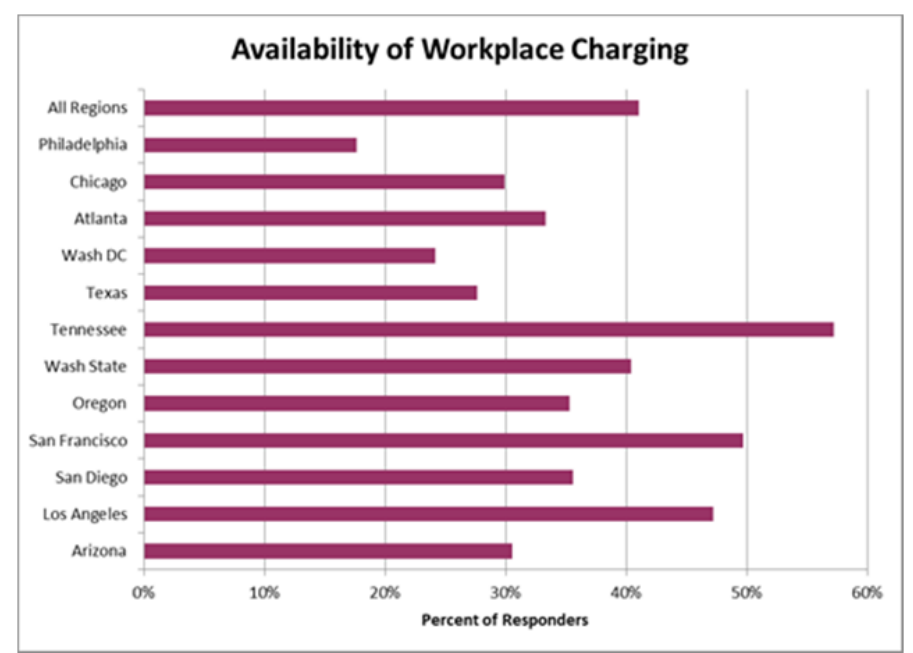

Figure 2. Availability and use of workplace charging by region.

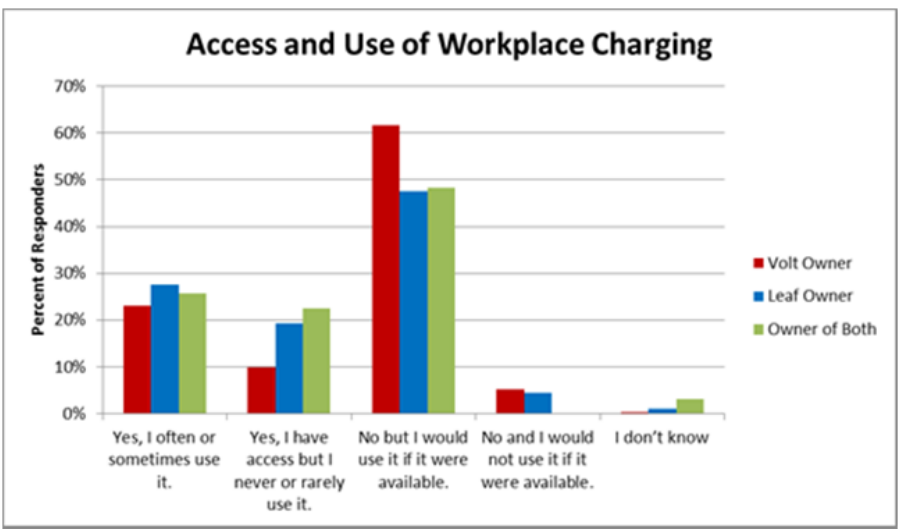

Figure 3. Availability and use of workplace charging by vehicle.

\section{Workplace Chargers}

The participants who had access to workplace charging were asked, "Is your workplace charging station...:" The response choices provided were as follows:

- $\quad$ AC Level 1 (120-volt AC - it may be a typical wall outlet to plug in the vehicle cordset)

- $\quad$ AC Level 2 (240-volt AC - equipment similar to your Blink unit at home, but could be supplied by other manufacturers)

- $\quad$ Direct Current (DC) Fast Charge (the connector plugs into the DC fast charge inlet on your Leaf).

More than one answer was allowed. The results are shown in Table 3.

The quantity of available DC fast chargers at work was not expected, although most responses were from San Francisco and Tennessee, where a significant number of DC fast chargers were installed.
Table 3. Workplace charger type.

\begin{tabular}{|c|c|}
\hline Type & Responders \\
\hline AC Level 1 & 411 \\
\hline AC Level 2 & 802 \\
\hline DC Fast Charger & 148 \\
\hline Total & 1,361 \\
\hline
\end{tabular}

\section{Importance of Workplace Charging}

The participants who had access to workplace charging were asked, "How important is workplace charging in meeting your EV driving needs?" The response choices provided were as follows:

- Essential - could not use my EV without workplace charging

- Very important - strongly desire full charge flexibility when leaving work

- Important - nice to have the added flexibility

- Somewhat important - I rely on workplace charging for my peace of mind

- Not important - I do not need workplace charging to meet my planned EV needs.

Figure 4 shows distribution of the 1,166 responses received.

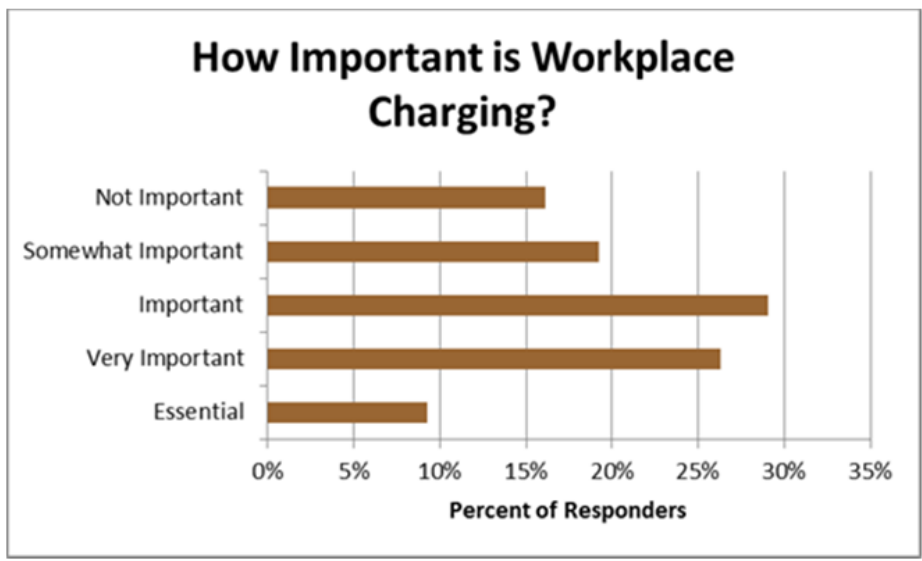

Figure 4. Importance of workplace charging.

Thirty-six percent of the responders reported that workplace charging was very important or essential to meeting their EV driving needs.

One of the questions explored in the report on home charging dealt with how much of the participant's charging needs are met by home charging. The importance of workplace charging was compared to the responses on where charging needs are met. Table 4 shows the results with workplace charging in the columns and charging needs met in the rows.

Seventy-two percent of the responders who reported a significant amount of charging away from home (i.e. "mostly use charging away from home" or "rely on away-from-home 
charging as much as home charging") rated workplace charging as important. Overall, $9 \%$ of responders reported workplace charging to be essential to their use of the EV. For others, the availability of workplace charging may not be essential, but they certainly relied on it as part of their daily routine.

Table 4. Importance of workplace charging versus charging location.

\begin{tabular}{|c|c|c|c|c|c|c|}
\hline $\begin{array}{l}\text { Importance of Workplace Charging } \\
\text { vs Where Charging Needs are Met }\end{array}$ & $\begin{array}{c}\text { Total } \\
\text { Responses }\end{array}$ & $\begin{array}{c}\text { Workplace } \\
\text { Essential }\end{array}$ & $\begin{array}{c}\text { Workplace } \\
\text { Very } \\
\text { Important }\end{array}$ & $\begin{array}{l}\text { Workplace } \\
\text { Important }\end{array}$ & \begin{tabular}{|c|} 
Total of \\
Workplace \\
Importance \\
\end{tabular} & $\begin{array}{l}\% \text { of Total } \\
\text { Responses }\end{array}$ \\
\hline $\begin{array}{l}\text { Away from home charging is not } \\
\text { a vailable in my area. }\end{array}$ & 42 & & & 1 & 1 & $2 \%$ \\
\hline $\begin{array}{l}\text { Never use charging away from } \\
\text { home }\end{array}$ & 664 & & & 36 & 36 & $5 \%$ \\
\hline $\begin{array}{l}\text { Occasionally us e charging away } \\
\text { from home }\end{array}$ & 1916 & 30 & 115 & 246 & 391 & $20 \%$ \\
\hline $\begin{array}{l}\text { Frequently use charging away from } \\
\text { home }\end{array}$ & 298 & 34 & 103 & 38 & 175 & $59 \%$ \\
\hline $\begin{array}{l}\text { Rely on away-from-home charging } \\
\text { as much as home charging }\end{array}$ & 136 & 38 & 54 & 6 & 98 & $72 \%$ \\
\hline $\begin{array}{l}\text { Mostly use charging away from } \\
\text { home }\end{array}$ & 60 & 6 & 26 & 11 & 43 & $72 \%$ \\
\hline Ra rely, if ever use home charging & 13 & & 3 & 1 & 4 & $31 \%$ \\
\hline
\end{tabular}

Of the 663 responders who reported workplace charging was available and they often or sometimes used it, $52 \%$ reported it was very important or essential in meeting their planned PEV needs. Of the 448 who reported workplace charging was available but they rarely or never used it, 40 reported it was very important or essential in meeting their planned PEV needs. The apparent inconsistency in response of these 40 people could either be an incorrect understanding of the question or that they see their occasional use as very important or essential.

\section{Publicly Accessible Charging}

\section{Use of Publicly Accessible Charging}

Participants were asked, "How often do you use public charging?" In all, 2,912 responses were received and are shown in Figure 5.

How Often do you use Publicly Accessible Charging?

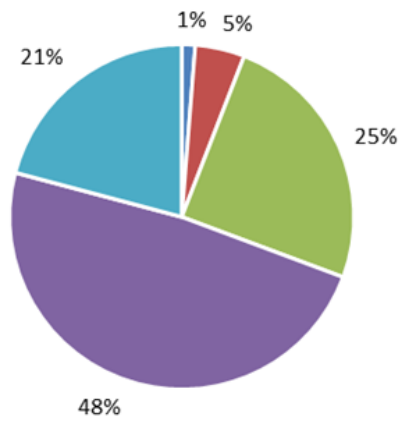

- Daily

- A few times per week

- A few times per month

- Very rarely

- I have never used public charging
Sixty-nine percent of responders reported they very rarely or never use public charging.

Prior to sending the survey, the participants were segmented by their vehicle type and charge data, which indicated one of the following: they never charged away from home, they occasionally charged away from home, they frequently charged away from home, and those whose typical behavior could not be determined because of GPS or other data inconsistencies. The response to this question was analyzed using the segmented group. The segmented groups, based on data collected, are represented by the columns and their responses to this question are in the rows of Table 5.

Table 5. Use of public charging by segmented groups.

\begin{tabular}{|l|c|c|c|c|c|c|c|c|}
\hline \multicolumn{1}{|c|}{$\begin{array}{c}\text { Use of Public } \\
\text { Charging Locations }\end{array}$} & $\begin{array}{c}\text { Leaf } \\
\text { Never }\end{array}$ & $\begin{array}{c}\text { Leaf } \\
\text { pccasional }\end{array}$ & $\begin{array}{c}\text { Leaf } \\
\text { Frequent }\end{array}$ & $\begin{array}{c}\text { Leaf } \\
\text { Unknown }\end{array}$ & $\begin{array}{c}\text { Volt } \\
\text { Never }\end{array}$ & $\begin{array}{c}\text { Volt } \\
\text { Occasiona }\end{array}$ & $\begin{array}{c}\text { Volt } \\
\text { Frequent }\end{array}$ & $\begin{array}{c}\text { Volt } \\
\text { Unknown }\end{array}$ \\
\hline Daily & 1 & 6 & 4 & 16 & 0 & 2 & 2 & 4 \\
\hline $\begin{array}{l}\text { A few times per } \\
\text { week }\end{array}$ & 0 & 40 & 8 & 40 & 1 & 16 & 8 & 2 \\
\hline $\begin{array}{l}\text { A few times per } \\
\text { month }\end{array}$ & 14 & 307 & 20 & 219 & 6 & 105 & 23 & 18 \\
\hline $\begin{array}{l}\text { Very Rarely } \\
\text { Never used public } \\
\text { Charging }\end{array}$ & 51 & 548 & 24 & 436 & 52 & 242 & 50 & 27 \\
\hline
\end{tabular}

The red responses show inconsistency between the participant's responses and their charge data. For Leaf owners whose charge data indicated they had never charged away from home, 15 reported that they did so daily or a few times per month. Yellow highlighted responses indicate a potential inconsistency. There may be inconsistencies for 133 Leaf owners whose charge data showed occasional or frequent away from home charging, but the responses reported never using public charging (although they may have used workplace charging).

Of the 42 responders who reported that away-from-home charging was not available in their area, 13 reported they had used public charging. Of the 664 responders who reported that they never used charging away from home, 232 reported that they had used public charging. The reasons for these inconsistencies by individuals in different questions but in the same survey instrument are unknown.

\section{Workplace and Public Charging}

The survey questions concerning home charging previously reported ${ }^{5}$ included the question "How much of your charging needs are met by home charging?" Table 6 compares the top responses involving the most away-fromhome charging to the responses on the use of workplace and the use of publicly accessible charging. Because the responses came from separate questions, the responses in each category may not be equal. For example, in the question on home charging, 13 reported that they rarely if ever use home charging. In the question on Workplace charging, of those 13, 2 reported they have access but

Figure 5. Use of publicly accessible charging. 
rarely use it and 5 reported they often or sometimes use it, while one of those original 13 reported they use public charging a few times per month. The other 5 of the original 13 responded with different choices.

Table 6. Away-from-home charging summary.

\begin{tabular}{|c|c|c|c|}
\hline Home Charging & \begin{tabular}{|c|}
$\begin{array}{c}\text { Total } \\
\text { Responses }\end{array}$ \\
\end{tabular} & \begin{tabular}{|c|} 
Workplace \\
Charging \\
\end{tabular} & $\begin{array}{c}\text { Public } \\
\text { Charging } \\
\end{array}$ \\
\hline $\begin{array}{l}\text { Rarely, if ever use home charging } \\
\text { Yes, I have access but I never or rarely use it. } \\
\text { Yes, I often or sometimes use it. } \\
\text { A few times per month } \\
\text { A few times per week } \\
\text { Daily }\end{array}$ & 13 & $\begin{array}{l}2 \\
5\end{array}$ & 1 \\
\hline Total & 13 & 7 & 1 \\
\hline $\begin{array}{l}\text { Mostly use charging away from home. } \\
\text { Yes, I I ave access but I never or rarely use it. } \\
\text { Yes, I often or sometimes use it. } \\
\text { A few times per month } \\
\text { A few times per week } \\
\text { Daily } \\
\end{array}$ & 60 & $\begin{array}{c}6 \\
37\end{array}$ & $\begin{array}{c}11 \\
10 \\
3 \\
\end{array}$ \\
\hline Total & 60 & 43 & 24 \\
\hline $\begin{array}{l}\text { Rely on away-from-home charging as much as home charging. } \\
\text { Yes, I have access but I never or rarely use it. } \\
\text { Yes, I often or sometimes use it. } \\
\text { A few times per month } \\
\text { A few times per week } \\
\text { Daily } \\
\end{array}$ & 136 & $\begin{array}{c}2 \\
102\end{array}$ & $\begin{array}{l}26 \\
16 \\
11\end{array}$ \\
\hline Total & 136 & 104 & 53 \\
\hline
\end{tabular}

For those most familiar with away-from-home charging and who used it, workplace charging appears to hold a higher level of importance than public charging.

\section{Describe Use of Publicly Accessible Charging}

Responders were asked to describe their use of publicly accessible charging. Free-form responses were allowed and the 750 responses generally fell into 18 separate categories as shown in Table 7.

Table 7. Participant's use of public charging.

\begin{tabular}{|l|c|}
\hline Describe your use of public charging. & Responses \\
\hline I use it if it is convenient to my destination & 208 \\
I use it to extend the range of my EV & 117 \\
Occasionally when beyond Leaf range and I need to get home & 88 \\
I only use public EVSE that are free of charge & 70 \\
There are no public chargers where I go & 64 \\
I've tried it once or twice only & 42 \\
I primarily charge on DC Fast Chargers & 35 \\
I don't use because there are always other cars parked at the EVSE & 29 \\
I use if no other option is available/Emergency use only & 25 \\
I use to demonstrate support for public charging & 15 \\
I tried it just to check it out with my EV & 15 \\
It allows me preferential parking & 11 \\
I don't use because stations are out of service or unreliable & 11 \\
I try to use public EVSE in a lot of different places & 8 \\
I will choose a business to patronize if it has public EVSE & 8 \\
I will charge only if I am there for > X hours & 3 \\
It helps me reduce my gas usage in the Volt & 1 \\
\hline
\end{tabular}

Generally, it can be expected that publicly accessible charging will only be used if it is relatively convenient to the destination of the PEV driver or along their intended route, which is shown by the most common comments provided. The difference between responses 2 and 3 is interpreted as the former is a planned excursion beyond the range of the Leaf while the latter is an instance of the Leaf owner traveling beyond the vehicle range, due to extra errands or stops that were not planned at the outset of the trip. In both cases, public charging is required to complete the trip home. The responses of "I use if no other option is available/emergency use only" typically reflected planned trips that were expected to be well within the battery range of the vehicle and depleting the battery charge was an unexpected event.

\section{Increasing Public Charging}

Participants were asked, "What do you suggest could be done to increase use of public charging?" This was a free form comment section. In all, 2,253 individual informative responses were received.

The responses were aggregated into 23 suggestions (see Table 8).

Table 8. Comments on increasing public charging.

\begin{tabular}{|l|c|}
\hline Comment & Responses \\
\hline Provide more charging in more locations (especially where I want to go) & 774 \\
Install more DC Fast Chargers & 501 \\
The fe e is a concern. Make them free or more comparable to home charging & 465 \\
Provide be tter signage, smart apps, maps, location information & 138 \\
Enforce EV parking only by fining or towing non-Evs & 82 \\
Provide credit card readers or inte rope rability between ne twork providers & 52 \\
Provide greater equipment reliability and operational readiness & 40 \\
Hosts could re duce costs with marketing incentives, coupons, advertising, etc. & 37 \\
Add more chargers to current locations. These are always in use. & 36 \\
Provide a reservation system so I know a charger will be available for me & 33 \\
Provide government subsidies and incentives to charging site hosts & 31 \\
The use will naturally expand with increasing PEV sales & 19 \\
Public Charging is pointless or unne cessary. & 10 \\
Provide better instructions on how to use & 7 \\
Provide more user friendly charge rs & 7 \\
Combine the charging site with Solar to re duce costs & 6 \\
Use more AC Level 1 in public & 6 \\
Standarize practices for parking lots and chargers to eliminate surp rises & 3 \\
Standardize the plugs for use by all EVs (i.e. DCFC, Tesla, etc) & 2 \\
Employers should extend employee bene fits to encourage public charging & 1 \\
Add design features to stations to allow vehicle-to-grid payments & 1 \\
Provide bikes or other transportation at charger to get to destination & 1 \\
Design full service charging station including convenience store and valet & 1 \\
\hline
\end{tabular}

It is of interest to segregate responses by those who most frequently charge away from home; both by written response and by vehicle charge data. Participant responses to previous questions in the survey that they "rarely use home charging", "mostly charge away from home", or "rely on away-from-home charging as much as home charging" are shown in the first 3 columns of Table 9. For those who provided the specific comment, their actual vehicle charge data were queried to identify whether they indeed had frequent away-from-home charging. Those responses are shown in the two right columns of Table 9. Because the survey information and the vehicle charge data come from different sources, the totals in the right two 
columns may be different from those in the left three columns. This may also reflect inconsistencies in the individual's responses (e.g. vehicle charge data demonstrates frequent use of away-from-home charging, but the individual does not respond as such in the survey).

The most frequent response (i.e., 34\%) was to expand the deployment of public charging to more locations. Typically, responses indicated that drivers were not able to find public charging in locations they frequent. The next highest suggestion indicates that there is a strong desire for more DC fast chargers in all regions. Although the Volt does not have fast charge capability, this was recognized by some Volt responders as important. Third, a high percentage of respondents identified the cost of public charging as a negative. Many thought that public charging should be at no cost or at most, the same cost, as they would be charged at home.

Table 9. Increasing use of public charging comments from high users.

\begin{tabular}{|c|c|c|c|}
\hline $\begin{array}{c}\text { Comments From Responders who Report HIGH use of Away-from-home } \\
\text { charging }\end{array}$ & $\begin{array}{c}\text { Rarely Use } \\
\text { Home } \\
\text { Charging }\end{array}$ & $\begin{array}{c}\text { Mostly } \\
\text { Charge Away } \\
\text { from Home }\end{array}$ & \begin{tabular}{|c} 
Rely on Away \\
from Home \\
Charging
\end{tabular} \\
\hline Provide more charging in more locations (especially where I want to go) & 2 & 13 & 38 \\
\hline The fee is a concern. Make them free or more comparable to home charging & 3 & 15 & 24 \\
\hline Install more DC Fast Chargers & 3 & 7 & 16 \\
\hline Provide better signage, smart apps, maps, location information & & 3 & 7 \\
\hline Enforce EV parking only by fining or towing non-Evs & & & 3 \\
\hline Hosts could reduce costs with marketing incentives, coupons, advertising, etc. & & 1 & 2 \\
\hline Provide greater equipment reliability and operational readiness & & & 2 \\
\hline Standarize practices for parking lots and chargers to eliminate surprises & & & 1 \\
\hline Use more AC Level 1 in public & & & 1 \\
\hline Provide better instructions on how to use & & & 1 \\
\hline The use will naturally expand with increasing PEV sales & & & 1 \\
\hline Provide government subsidies and incentives to charging site hosts & & 1 & 1 \\
\hline Provide a reservation system so I know a charger will be available for me & & 1 & 1 \\
\hline Add more chargers to current locations. These are always in use. & & & 1 \\
\hline Public Charging is pointless or unnecessary. & & 1 & \\
\hline Provide credit card readers or interoperability between network pro & & 1 & \\
\hline
\end{tabular}

\begin{tabular}{|c|c|}
\hline $\begin{array}{c}\text { Charge } \\
\text { Data Leaf } \\
\text { Frequent }\end{array}$ & $\begin{array}{c}\text { Charge } \\
\text { Data Volt } \\
\text { Frequent }\end{array}$ \\
\hline 20 & 30 \\
7 & 29 \\
17 & 2 \\
1 & 8 \\
2 & 2 \\
& 3 \\
& 1 \\
& \\
& \\
& \\
& \\
& \\
& \\
& \\
& \\
& \\
& \\
& \\
& \\
& \\
& \\
& \\
& \\
& \\
& \\
& \\
& \\
& \\
& \\
&
\end{tabular}

Table 10. Increasing use of public charging comments from non-users.

\begin{tabular}{|c|c|c|c|c|}
\hline $\begin{array}{c}\text { Comments From Responders who Report NO use of Away-from-home } \\
\text { charging }\end{array}$ & $\begin{array}{c}\text { Away from } \\
\text { Home } \\
\text { Unavailable }\end{array}$ & $\begin{array}{c}\text { Never Charge } \\
\text { Away from } \\
\text { Home }\end{array}$ & \begin{tabular}{|c} 
Charge \\
Data - Leaf \\
Never
\end{tabular} & $\begin{array}{c}\text { Charge } \\
\text { Data - Volt } \\
\text { Never }\end{array}$ \\
\hline Provide more charging in more locations (especially where I want to go) & 17 & 143 & 26 & 49 \\
\hline The fee is a concern. Make them free or more comparable to home charging & 5 & 89 & 8 & 28 \\
\hline Install more DC Fast Chargers & 3 & 73 & 30 & 6 \\
\hline Provide better signage, smart apps, maps, location information & 2 & 23 & 5 & 12 \\
\hline Provide credit card readers or interoperability between network providers & & 16 & 4 & 1 \\
\hline Enforce EV parking only by fining or towing non-Evs & & 14 & 3 & 4 \\
\hline Provide government subsidies and incentives to charging site hosts & 1 & 7 & 2 & 4 \\
\hline Provide a reservation system so I know a charger will be available for me & & 6 & 1 & 2 \\
\hline Public Charging is pointless or unnecessary. & & 5 & & \\
\hline The use will naturally expand with increasing PEV sales & 1 & 5 & & 2 \\
\hline Hosts could reduce costs with marketing incentives, coupons, advertising, etc. & & 5 & 2 & 4 \\
\hline Provide more user friendly chargers & & 4 & 2 & 1 \\
\hline Add more chargers to current locations. These are always in use. & 2 & 4 & 2 & 1 \\
\hline Provide greater equipment reliability and operational readiness & & 4 & 2 & 1 \\
\hline Provide better instructions on how to use & & 3 & 1 & \\
\hline Add design features to stations to allow vehicle-to-grid payments & & 1 & & \\
\hline
\end{tabular}


Just as it was important to view the responses of those who frequently charged away from home, it might be instructive to view the comments from those who do not. Table 10 provides the results of the comments from those who self-identified that away-from-home charging was not available to them or that they never charged away from home; they are represented in the first two columns of Table 10. A review of their actual vehicle charge data also identified those who never charge away from home, both for the Leaf and the Volt. Those responses are shown in the two right columns of Table 10. As before, the totals in the right two columns may not match the totals in the left two columns.

The top three suggestions are the same for those not using public charging as those using public charging. However, responses from non-users also emphasized making it easier for people to find public charging in maps or apps, to know how to use it through education and easier to use EVSE, and to have it available when they arrive through reservations, including interoperability of membership cards, etc. It appears that for those who have not used public charging, there is apprehension about trying it.

\section{Conclusions}

Overall, $15 \%$ of all charging events by The EV Project participants were performed away from home. This away-from-home charging can occur either at work or at publicly accessible EVSE. The survey responses showed that a significant percentage (i.e., $41 \%$ ) of the survey respondents had access to workplace charging. For those who had charging available at work, over onethird reported that using workplace charging was very important or essential to their use of the PEV. Many others would use workplace charging if it were provided to them.

Publicly available charging, on the other hand, was not as accepted for meeting PEV charging needs. A significant percentage (i.e., $69 \%$ ) reported never using or very rarely using public charging. While many comments suggest that expanding the infrastructure would provide more public EVSE in places they frequent, it is unclear whether they would be willing to pay the access fees necessary to support that expansion.

\section{About The EV Project}

The EV Project was the largest PEV infrastructure demonstration project in the world. Equally funded by DOE through the American Recovery and Reinvestment Act and private sector partners, it supported the initial rollout of the Nissan Leaf and Chevrolet Volt PEVs, as well as the first deployment of PEVs in an all-PEV ride share application. The EV Project deployed over 12,000
AC Level 2 charging stations and over 100 dual-port DC fast chargers in 16 metropolitan areas across the United States during the period January 1, 2011, through December 31, 2013. Drivers of approximately 8,300 Nissan Leafs, Chevrolet Volts, and Smart ForTwo Electric Drive vehicles were enrolled in the project.

Project participants allowed EV Project researchers to collect and analyze data from their vehicles and chargers. Data collected from project vehicles and charging infrastructure document nearly 125 million miles of driving and over 4 million charging events in significant detail, characterizing the earliest days of electric vehicle adoption through significant penetration of both the vehicles and charging infrastructure. The data reside at Idaho National Laboratory, which is responsible for analyzing the data and publishing summary reports, technical papers, and lessons learned on vehicle and charger use.

\section{Company Profile}

Idaho National Laboratory is one of DOE's 10 multi-program national laboratories. The laboratory performs work in each of DOE's strategic goal areas: energy, national security, science, and the environment. Idaho National Laboratory is the nation's leading center for nuclear energy research and development. Day-today management and operation of the laboratory is the responsibility of Battelle Energy Alliance.

For more information, visit avt.inl.gov/evproject.shtml and avt.inl.gov/chargepoint.shtml.

\section{References}

1"EV Project Participant and Charging at Home," Lessons Learned, avt.inl.gov/evproject.shtml.

"Who are the Participants in The EV Project," Lessons Learned, avt.inl.gov/evproject.shtml.

3 "How do The EV Project Participants feel about their EV?" Lessons Learned, avt.inl.gov/evproject.shtml.

${ }^{4} E V$ Project EVSE and Vehicle Usage Report $2^{\text {nd }}$ Quarter 2013, avt.inl.gov/evproject.shtml.

${ }^{5}$ op.cit. Charging at home. 